\title{
Polymorphism Analysis
}

National Cancer Institute

\section{Source}

National Cancer Institute. Polymorphism Analysis. NCI Thesaurus. Code C18309.

Chemical or physical tests to determine DNA sequence variation 